DOI: $10.19085 /$ journal.sijmas030802

\title{
An Anthropometric study on Kinanthropometry and motor fitness among Kho- Kho Players
}

\author{
'Ashish Kumar Singh \& ${ }^{2}$ Dr. Ajeet Jaiswal. \\ ${ }^{1}$ Asst. Professor, Department Phy. Edu. HNBGU, Srinagar Garhwal, Uttarakhand, India. \\ ${ }^{2}$ Asst. Professor, Department of Anthropology, Pondicherry University, Puducherry, India \\ ๑ Scholedge International Journal of Multidisciplinary \& Allied Studies (ISSN 2394-336X), Vol.03, Issue 08 (2016) pg142-147. \\ Published by: Scholedge R\&D Center [http://www.thescholedge.org/journals/] [Email: editorial@thescholedge.org]
}

\begin{abstract}
The purpose of this research was to establish the relationship between kinanthropometry and motor fitness and kho-kho playing abilities. One hundred and forty five women players were selected from the students of Pondicherry University during the South Zone kho-kho tournament. Playing ability was measured with the help of three kho-kho experts; kinanthopometric measurements such as height, weight, leg length and arm length were measured with the help of the ISAK guideline manual; and among motor fitness abilities, agility was measured by 40-m shuttle run, leg explosive power by standing broad jump, flexibility by sit and reach test, and muscular endurance was measured by knee bent sit-up test. The kho-kho playing ability was assessed by three well qualified and experienced experts. There were high correlations existing between playing abilities with Agility $(r=0.63)$, Explosive leg Power $(r=0.59)$, Muscular endurance $(r=0.39)$.
\end{abstract}

Keywords: Kinanthropometric, Motor fitness, Kho-kho, Muscular endurance.

\section{Introduction}

Kho-Kho is a game of Indian origin and is played outdoors. It requires well-developed biomotor abilities (Tudor O. Bompa) such as speed, strength, coordination etc. along with intelligence and abilities to make quick decisions. The important body movements in this game involve catching, holding, locking and jumping; thus the possession of desirable kinanthropometric and motor fitness characteristics will be a great advantage for better performance in competitions.

"Kinanthropometry has been defined as the quantitative interface between human structure and function" (Rose et al.); and also it distinguishes individual diversity because body type plays a tremendous role in all kinds of games. In all kinds of sports, certain physical characteristics such as body type (somatotyping) and body composition can significantly influence athletic performance 
(Carter, 1970, Duquet and Carter, 2012). By applying kinanthropometry in all kind of sports we can attempt to design the working environment around the persons rather than placing constraints on them because they have to adapt to what is provided. If kinanthropometry parameters are taken into consideration when products are designed, the outcome is likely to be increased acceptability along with improved ease and efficiency of use, and therefore greater operational safety and cost effectiveness. While considering the design and use of equipment, the term 'average person' is often referred to and used. The body is made up anthropometrically of several functional parts such as sitting height, stature, leg length and weight etc.

The aim of present study is to find out the possible inter-correlation between selected kinanthropometric parameters and motor fitness in the contexts of the playing abilities of south zone women kho-kho players and also find out the possible predictor parameters which can predict the kho-kho playing ability with the help of the linear regression model.

The standing long jump test for explosive strength (the ability to expend maximum energy in one explosive act), and 40-m agility test were used to determine the power of moving quickly and easily without losing speed etc.

\section{Method And Materials}

\subsection{Subjects}

For the present study 145 women kho-kho players were selected from the South Zone khokho tournament in the year 2014 of ages spanning 17 to 26 years. The convenient sampling method was applied to collect the sample.

\subsection{Selection of variables}

For this study, kho-kho playing ability was selected as the criterion variable and kinanthropometry and motor fitness were selected as predictor variables.

\subsection{Administration of kinanthropometry and motor fitness}

kinanthropometric variables, such as height, were measured by the means of a stadiometer (Seca 220 , UK), to the nearest $0.1 \mathrm{~cm}$ and leg length and arm length were measured in $\mathrm{cm}$ with the help of an anthropometric rod. All the kinanthropometric measurements were taken as per the ISAK manual 2011 (Gredelj, et. al., according to Rodić, 2011). Motor fitness such as Leg explosive power was measured to the nearest $0.1 \mathrm{~cm}$ with the help of the standing broad jump test. Agility was measured with the help of $4 \times 15-\mathrm{m}$ agility run test. Time in seconds and hundreds of seconds was determined using an electronic timing system (Micro Gate, IT). Muscular endurance was measured with the help of numbers knee-bend sit-up. Grip strength was measured in kg using grip-strength dynamometer. Flexibility was measured to the nearest $0.1 \mathrm{~cm}$ with the help of sit and reach test. 


\subsection{Statistical Technique}

Descriptive statistics such as mean and standard deviation were applied to characterize the kho-kho playing ability, kinanthropometric parameters, and motor fitness abilities of the South Zone kho- kho players. Correlation was applied to establish the relationship among them. Linear regression was used to predict the kho- kho playing ability. The level of significant was kept as $\mathrm{P}<0.05$.

\section{Results \& Discussion}

Table-1: Mean and Standard Deviation of kho- kho players

\begin{tabular}{|l|l|r|r|}
\hline S.No & Variables & Mean $\mathbf{( n = 1 3 0 )}$ & S.D. \\
\hline & Playing ability & 7.4 & .72 \\
\hline 1. & Height & 171.3 & 5.9 \\
\hline 2. & Weight & 65.1 & 7.1 \\
\hline 3. & Leg length & 98.4 & 6.1 \\
\hline 4. & Arm length & 72.54 & 3.6 \\
\hline 5. & Agility & 12.1 & .65 \\
\hline 6. & Explosive power & 181.8 & 8.3 \\
\hline 7. & Sit-ups & 47.7 & 6.9 \\
\hline 8. & Grip strength & 49.9 & 6.3 \\
\hline 9. & Flexibility & 21.7 & 2.8 \\
\hline
\end{tabular}

Table -1 show the Mean and Standard Deviation of kinanthropometric and motor fitness of khokho players. The discussion of the findings with regard to descriptive statistics such as the mean values and S.D. showed that South Zone women kho-kho players possess the above-mentioned characteristics which will be helpful in selecting a good kho-kho player in future from the South Zone with respect to the kinanthropometric and motor fitness contexts.

TABLE-2: Results Of Correlation

\begin{tabular}{|l|l|l|l|l|l|l|l|l|l|}
\hline Variables & $\begin{array}{l}\text { Heigh } \\
\mathrm{t}\end{array}$ & $\begin{array}{l}\text { Weigh } \\
\mathrm{t}\end{array}$ & $\begin{array}{l}\text { Leg } \\
\text { lengt } \\
\mathrm{h}\end{array}$ & $\begin{array}{l}\text { Arm } \\
\text { lengt } \\
\mathrm{h}\end{array}$ & $\begin{array}{l}\text { Agilit } \\
\mathrm{y}\end{array}$ & $\begin{array}{l}\text { Explosiv } \\
\text { e Power }\end{array}$ & $\begin{array}{l}\text { Grip } \\
\text { strengt } \\
\mathrm{h}\end{array}$ & $\begin{array}{l}\text { Flexibilit } \\
\mathrm{y}\end{array}$ & $\begin{array}{l}\text { Muscular } \\
\text { enduranc } \\
\mathrm{e}\end{array}$ \\
\hline $\begin{array}{l}\text { Playing } \\
\text { ability }\end{array}$ & .087 & .221 & .30 & .27 & .631 & .59 & .121 & .19 & .391 \\
\hline Height & & .33 & .74 & .64 & .21 & .17 & .13 & .09 & .16 \\
\hline Weight & & & .19 & .20 & .15 & .11 & .22 & .25 & .08 \\
\hline $\begin{array}{l}\text { Leg } \\
\text { length }\end{array}$ & & & & .43 & .08 & .18 & .05 & .12 & .06 \\
\hline
\end{tabular}




\begin{tabular}{|c|c|c|c|c|c|c|}
\hline $\begin{array}{l}\text { Arm } \\
\text { length }\end{array}$ & 0 & 0.9 & .21 & 0.7 & .15 & .09 \\
\hline Agility & & & .14 & .05 & .11 & .07 \\
\hline $\begin{array}{l}\text { Explosiv } \\
\text { e Power }\end{array}$ & & & & .09 & .24 & .08 \\
\hline $\begin{array}{l}\text { Grip } \\
\text { strength }\end{array}$ & & & & & .10 & .22 \\
\hline $\begin{array}{l}\text { Flexibilit } \\
\text { y }\end{array}$ & & & & & & .09 \\
\hline
\end{tabular}

*Significant at $(P<0.05)$

Table -2 shows that there were high correlations between playing ability and agility ( $r=$ 0.631), explosive leg power $(r=0.59)$, muscular endurance $(r=0.391)$; and moderate correlations exist between playing ability and arm length $(r=0.271)$, leg length $(r=.30)$, weight $(r=0.221)$, flexibility $(r=0.19)$; and low correlations exist between playing ability and grip strength $(r=0.121)$; and very low correlation for height $(r=0.087)$ with playing ability in kho- kho.

Table - 3: Regression Model for Predictive Equation of the South Zone women kho-kho players

\begin{tabular}{|c|c|c|c|c|c|c|}
\hline \multirow{2}{*}{ Model } & \multirow{2}{*}{ Variables } & \multirow{2}{*}{$\begin{array}{l}\mathrm{R} \\
\mathrm{R} \\
\text { Square } \\
\text { Change }\end{array}$} & \multirow{2}{*}{$\begin{array}{l}\text { R Square } \\
\text { F Change }\end{array}$} & \multicolumn{2}{|c|}{$\begin{array}{l}\text { Unstandardized } \\
\text { Coefficients }\end{array}$} & \multirow{2}{*}{$\begin{array}{l}\begin{array}{l}\text { Standardized } \\
\text { Coefficients }\end{array} \\
\mathrm{R} \\
\text { Square } \\
\text { Change }\end{array}$} \\
\hline & & & & B & $\begin{array}{l}\text { Std. } \\
\text { Error }\end{array}$ & \\
\hline \multirow[t]{2}{*}{1.} & (Constant) & & & 4.032 & .617 & \\
\hline & $\begin{array}{l}\text { Leg Explosive } \\
\text { strength }\end{array}$ & $.694(a)$ & .512 & 3.314 & .431 & .695 \\
\hline \multirow[t]{3}{*}{2.} & (Constant) & & & 6.724 & 3.421 & \\
\hline & $\begin{array}{l}\text { Leg Explosive } \\
\text { strength }\end{array}$ & & & 2.962 & .3 .012 & .532 \\
\hline & Agility & .74 .20 (b) & .563 & -.571 & .198 & -.31 \\
\hline \multirow[t]{4}{*}{3.} & (Constant) & & & 8.731 & 2.471 & \\
\hline & $\begin{array}{l}\text { Leg Explosive } \\
\text { strength }\end{array}$ & & & 2.651 & .321 & .4 .92 \\
\hline & Agility & & & -.585 & $\begin{array}{l}.167 \\
\end{array}$ & -.253 \\
\hline & $\begin{array}{l}\text { Muscular } \\
\text { endurance }\end{array}$ & $.77 .57(c)$ & .607 & -.049 & .012 & -.249 \\
\hline 4. & (Constant) & & & 7.317 & 2.143 & \\
\hline
\end{tabular}




\begin{tabular}{|l|l|l|l|l|l|l|}
\hline & $\begin{array}{l}\text { Leg Explosive } \\
\text { Power }\end{array}$ & & & 2.41 & .221 & .4 .08 \\
\cline { 2 - 7 } & Agility & & & -.453 & .196 & -.236 \\
\cline { 2 - 7 } & $\begin{array}{l}\text { Muscular } \\
\text { endurance }\end{array}$ & & .041 & .09 & -.225 \\
\cline { 2 - 7 } & Leg length & $.794(\mathrm{~d})$ & .635 & -.360 & .091 & -.214 \\
\hline
\end{tabular}

*Significant at $(P<0.05)$.

Table -3 shows that the Regression Model for the Predictive Equation of South Zone women kho-kho players in the kinanthropometric and motor perspective. Leg explosive power scores accounted for 0.794 (69\%) in the first model of the performance ability. Agility, power, muscular endurance and leg length subsequently added significantly ( 0.01 and 0.05 levels) to predict the playing abilities in the run-up to the final model. The $\mathrm{R}^{2}$ value for the combination of leg explosive power, agility, muscular endurance, and leg length on playing ability was 0.794 (79\%) with the $R^{2}$ change $\left(R^{2}\right) .637$ for the final model.

\section{Linear Regression Model for kho-kho playing abilities}

Playing abilities = 7.317-.453 (Agility) +0.046 (Muscular endurance) + 2.41 (Leg Explosive power) 0.360 (leg length)

Kho-kho favors development of the body with agility, endurance, explosive power and also kinanthropometric parameters. Fine flexibility and agility is developed/ as one needs to move faster in a small area such as [16×29 sq. m]. The players' eyes and body movements become quicker. On the other hand, physical skills like speed, power [strength], endurance, flexibility, swift action, and proper coordination between hand eyes and limbs also develop (Devaraju \& Needhiraja). Kho-kho requires very good agility and explosive strength along with endurance, because in an enclosed space quick movements are very essential.

The present study provides the most accurate predictions of the kinanthropopmetric and motor fitness characteristics of South Zone women kho-kho players' playing ability and also shows that high correlations exist between playing ability and leg explosive power, agility and muscular endurance, because these factors are dominant in the game of kho-kho. These qualities must be possessed by good kho-kho players. Kinanthropometry (individual diversity) also plays a crucial role in all kinds of games.

\section{Conclusions}

1. The present study indicates that there was a high correlation between playing ability and agility, leg explosive power and muscular endurance. 
The results of the present study emphasize that the agility, leg explosive power, muscular endurance are common characteristics which can predict the kho-kho playing ability. The Linear Regression Model equation is--- 7.317-.453 (Agility) +0.046 (Muscular endurance) + 2.41 (Leg Explosive power) -

$$
0.360 \text { (leg length) }
$$

\section{References}

1. Bompa, Tudor O. (1999), Periodization: Theroy and Methodology of Training, $4^{\text {th }}$ Ed., Human Kinetics.

2. Verma, J. Prakash, A Text Book on Sports Statistics, Sports Publications.

3. Devaraju, K., and Kalidasan, R. (2012), Prediction of kabaddi playing from selected Anthropometrical and Physical variables among college level players. Asian journal of International Technology11(4):131 - 134

4. De AK, Debnath PK, Panda BK, Bhatacharya, AK. (1982) Physical efficiency and tests on Indian male kabaddi inter-university players. Br J Sports Med; 16: 33-6.

5. Bale, P. (1991). Anthropometric, body composition and performance variables of young elite female basketball players. Journal of Sports Medicine and Physical Fitness, 3, 173-177.

6. Sasa, Krstulovi.et al.,(2005), Anthropological Determinants of Success in Young Judoists. Coll. Antropol. 29 (2005) 2: 697-703UDC 796.853.23-053.6:572.087(497.5)

7. Bala,Gustav and Drid,Patrik, (2010) Anthropometric and Motor Features of Young Judoists in Vojvodina. Coll. Antropol. 34 (2010) 4: 1347-1353

8. Kalard, P.L. and Wahid, Abdul (2011). Personality Characteristics of Kabaddi and Kho-Kho Players, Variorum, Multi-Disciplinary e- Research Journal, Vol.01, Issuelll.

9. Fahiminezhad, Ali (2010). The study of anthropometric sizes and physical fitness factors of boy students aged 12 - 14 in Shahrood city. Br J Sports Med ; 44: 38 doi:10.1136/bjsm.2010.078725.124

10. Stewart A D, Marfell-Jones, M, Olds T, \& de Ridder,H. (2011). International Standards for Anthropometric Assessments, (ISAK)

11. Rodić, N. (2011). Teorija fizičkog vaspitanja [Theory of Physical Education.] Sombor: Pedagoški fakultet. 